\title{
On the possibility of using vitrified forts as anthropogenic analogues for assessment of long-term behaviour of vitrified waste
}

\author{
R. Sjöblom ${ }^{1}$, H. Ecke ${ }^{2}$ \& E. Brännvall ${ }^{1}$ \\ ${ }^{1}$ Luleå University of Technology, Sweden \\ ${ }^{2}$ Vattenfall Research and Development $A B$, Sweden
}

\begin{abstract}
An information survey was conducted in the areas of natural analogues, vitrified forts, combustion technology and vitrified waste. The main purpose was to identify if vitrified stone material in hillforts might be used as anthropogenic analogues for glass containing waste. Such comparisons are needed in order for predictions to be made regarding the long-term integrity of the waste forms. The scope was to compare the chemistry as well as the processes used for the generation of the glasses.

It was found that the vitrified forts contain glass material with wide variations in composition of the major elements. They cover and exceed those in the glasses made of waste with only the exception of phosphorus. Natural glasses as well as archaeological glasses show much narrower ranges of compositions, and they do not coincide with those of the glasses containing waste.

Quality of heat analyses indicated that it is likely that the stone material in the forts was melted for the purpose of obtaining long-lasting structures. This narrows the range of possible processes used, and facilitates reconstruction of the ancient methods by means of testing. This, in turn, provides possibilities of comparison between ancient and modern methods, which can then be used as a basis for validation of the use of the analogue.
\end{abstract}

Keywords: long-term, analogue, vitrification, hillfort, glass, leaching.

\section{Introduction}

Sustainability implies that waste is recycled as far as is reasonably achievable, and that the residues that cannot be used are landfilled in such a way that no 
burden is put on future generations. This implies that any hazardous substances are contained by means of immobilization and by impervious technical and natural barriers.

In general, glasses have a good capability of incorporating various elements in their structures. Glasses can also be given compositions that are very resistant to corrosion and weathering.

However, the evaluation and assessment of the functioning of such resistant structures over long times is fundamentally difficult, and we largely have to rely on natural and anthropogenic analogues, i. e. structures and materials that are similar and that have been in the environments in question for long times.

There are at least three waste forms comprising waste that has been vitrified, often together with additives:

- Ash from incineration of domestic waste and similar [1-6].

- Contaminated soil [7-10].

- Fission products from reprocessing of spent nuclear fuel [7, 11-14].

There are three types of analogues that might be utilised for assessment of the long-term behaviour:

- Natural glasses

- Glasses in archaeological specimens

- Glasses in vitrified hillforts

So far, studies have focussed on glass containing nuclear waste together with natural glasses and archaeological specimens as analogues. No rationale has been found in the literature for not including glass from vitrified forts. No studies have been found on studies of analogues in conjunction with vitrified ash and vitrified soil.

\section{Objectives}

The main objective of the present work is to evaluate the feasibility of using glass material in vitrified forts as anthropogenic analogues for vitrified waste.

The properties of a glass are strongly dependent on the chemical composition together with the details of the process in which the glass was generated.

Analysis of the significance of the chemical composition is quite straightforward since chemical analysis data are available, and since such data can also be readily obtained.

It is less straightforward to determine the likely process used, and this issue has been a matter of controversy for more than a century [15-18]. Some scientists have maintained that the vitrification was deliberate and served the purpose of joining the rocks. Others have maintained that vitrification occurred inadvertently and as a result of enemies burning the reinforcing timbers in the forts.

The objective of the present work is therefore also to identify the nature of the process used. Hopefully, such an identification would enable comparisons to be made between anthropogenic glass and similar contemporary glass. 


\section{Vitrified waste forms}

\subsection{Vitrified incinerator ash and additives}

Incinerator fly ash and bottom ash are generated as a result of incineration of domestic waste together with certain industrial waste (wood, paper and plastic) in a grate fired incinerator. Examples of compositions of such ashes are presented in Figure 1 [1]. Ashes are also obtained from fluidized bed incinerators. In such cases, the chemical composition of the bottom ash is influenced by the composition of the sand in the bed.

In some facilities in Japan, incinerator ash is melted together with additives at high temperatures to form a glass that is stable in ordinary outdoors environments [1-6]. In this way, trace elements are immobilized so that they cannot influence health and the environment. See also References [19-36].

\subsection{Vitrified contaminated soil}

In some cases in the United States, contaminated soil is stabilized in situ by means of an electric current that runs between graphite electrodes spaced a few metres apart [7-8]. The soil is made electrically conducting by introducing a current through a track of graphite, thus heating the adjacent soil to such temperatures that it starts to melt. Such partially melted soil contains ions that conduct electricity, and thus the process is made to escalate.

The chemical composition of soil can vary considerably, and not all compositions are suitable. Soils can have compositions similar to those in Figure 1 for incinerator ash, but with less sodium and perhaps also less potassium.

\subsection{Vitrified nuclear fission products and additives}

Glass containing nuclear fission products [7, 11-14] is generated in a few countries, including France, Japan and the United States. The spent nuclear fuel is dissolved and the fission products are separated. They are then heated together with additives to form a glass that constitutes a durable waste form in the intended environment.

Nuclear waste glasses differ considerably from other waste glasses by their loading of fission products and by their high content of phosphorus, see Figure 1.

\section{Natural and anthropogenic analogue glasses}

\subsection{Natural glasses}

Obsidian is a natural glass that has been used in studies as a natural analogue to nuclear waste glass. It was used for sharp tools in the neolithic era in areas where flint was not available [37]. Obsidian is formed from lava when it is cooled relatively rapidly so that crystallization does not take place. All obsidians have quite similar chemical compositions [37], and an example is presented in Figure 1. 
Obsidian has a high content of silica and low contents of sodium and potassium, and is therefore very resistant to corrosion and weathering [38].

\subsection{Archaeological glass artefacts}

Most of the archaeological glass objects were prepared from potash and sand rich in silica. Ash and sand could also be used. Such glasses have a high content of potassium and also sodium, and this makes the glass easy to melt. An example of a composition of this type of glass is presented in Figure 1 [38].

The composition of ancient Egyptian glass is somewhat different, however. Egypt has natural deposits from which people collected soda for the glass. It was used instead of potash or ash. Thus, Egyptian glass is high in sodium and low in potassium, see Figure 1 [38].

The high contents of sodium and potassium in ancient glasses make them susceptible to corrosion and weathering [38].

\subsection{Vitrified forts}

Glasses in vitrified forts show a large variety in chemical composition, between different forts as well as within a single fort. Examples of compositions can be found in Figure 1 [39-40].

\section{$5 \quad$ Vitrified forts}

\subsection{Hillforts and vitrified forts}

An example of a vitrified fort is shown in Figure 2.

A hillfort is an ancient fortification made from stone and earth and usually also logs [15-18, 39-42]. They date from $1000 \mathrm{BC}$ to $1400 \mathrm{AD}$ with most of the estimates in the period $500-0 \mathrm{BC}[39,41]$. It has been assessed [15] that there are up to 30000 hillforts in Europe. The number of forts with artificially vitrified walls has been estimated to 200, about half of them in Scotland, and 17 in Sweden [17]. There are two categories of "vitrification" depending on the composition of the rock material used [15]. Rock having a high content of calcium carbonate is calcined on heating. This implies that the material looses carbon dioxide and becomes reactive with water and air, and this leads to cementation of the structure in question. Rock low in calcium carbonate is instead susceptible to melting, and this leads to the stones in the structure becoming welded together by molten material that has re-solidified on cooling. It is likely that the number of vitrified forts is grossly underestimated since one has to dig and look for the vitrification in order to observe it. 


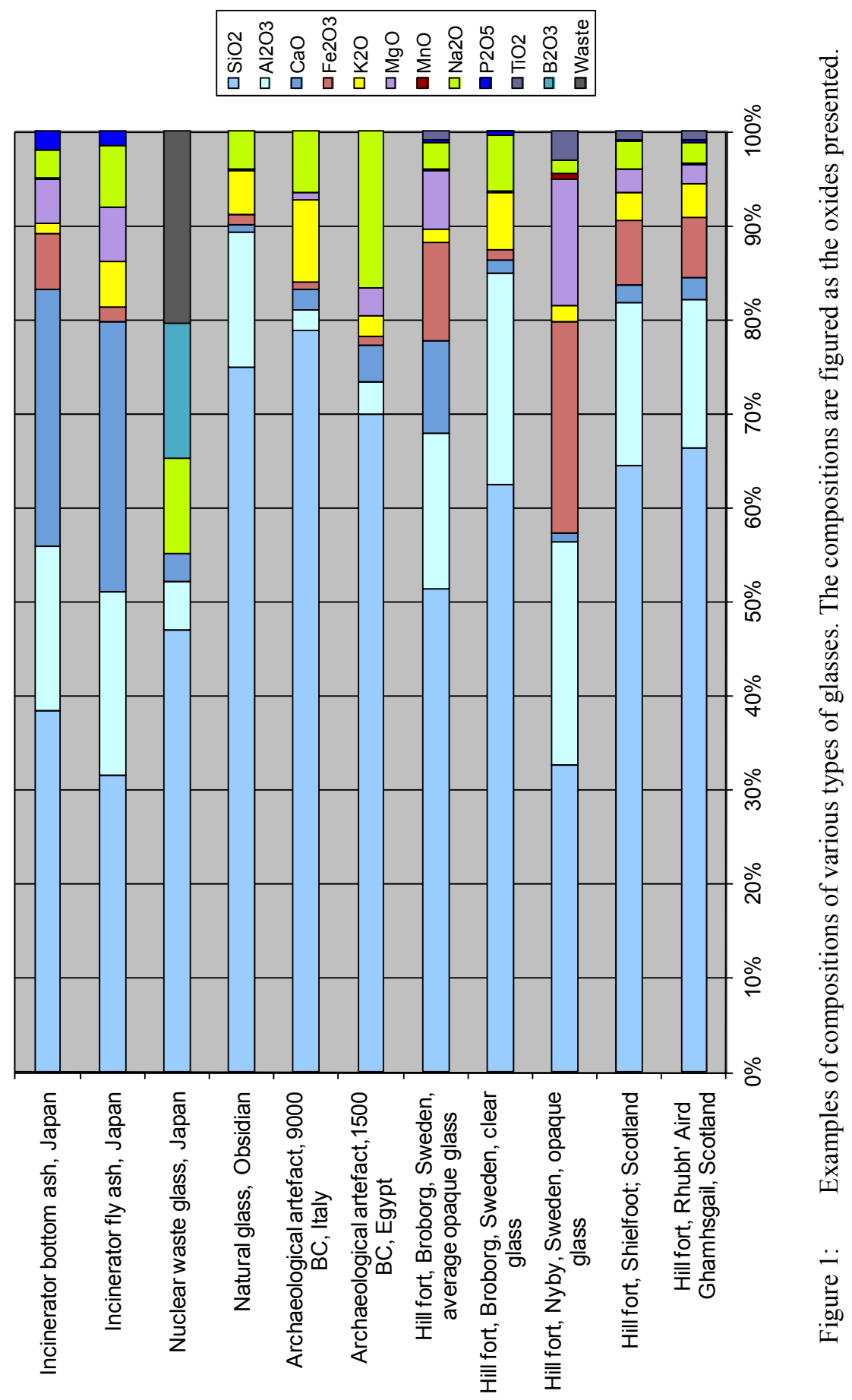




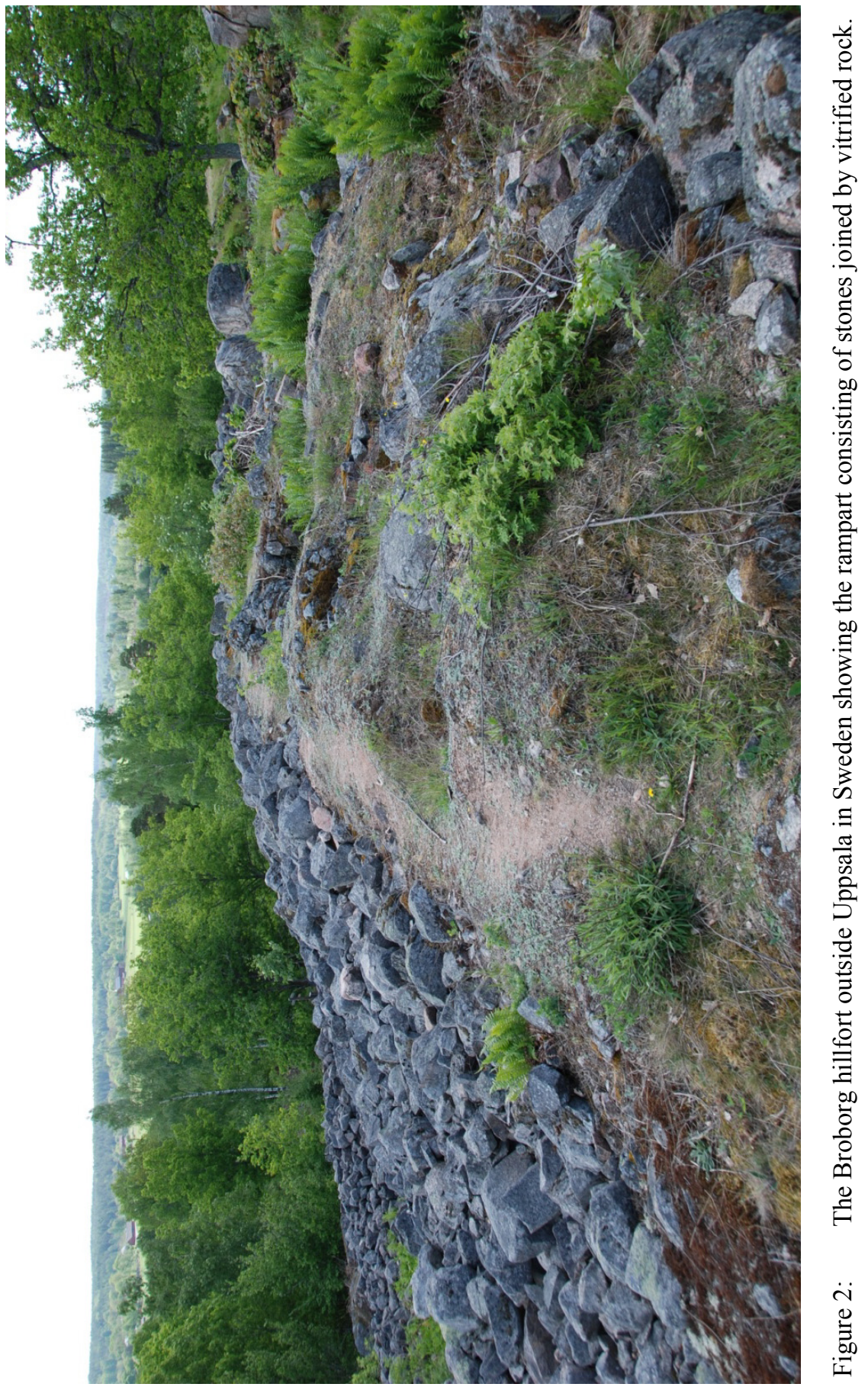




\subsection{Heat quality considerations}

It was mentioned above that there has been a century long scientific dialogue regarding the reason for the vitrification. It has been argued on one hand that people had access to charcoal and bellows for beneficiation and forging of iron, and that such practices were very widespread. On the other hand, tests have been carried out involving tons of stones and at least hundreds of kilograms of wood with little results in terms of vitrification. This has been interpreted to imply that a very large and destructive fire would be necessary.

It is put forward in the following, that it is not the number of Joules or Watts that is most crucial, but the quality of the heat.

In ordinary combustion of wood (i. e. without pre-heating) the maximum temperature becomes $700-1100{ }^{\circ} \mathrm{C}$. [43] The temperature needed for partial melting of typical stone material in a vitrified fort is $900-1100{ }^{\circ} \mathrm{C}$ [39-41, 44-46]. Much of the heat required is consumed for the melting. The numbers indicate that only a small fraction of the heat in the fumes could have been utilized to melt stone material.

Charcoal has a combustion temperature of perhaps $1300-1500{ }^{\circ} \mathrm{C}$ [43]. Thus fumes from burning of charcoal can lose a lot of heat before reaching the temperature of partial melting of the stone material. The ancient people had a good knowledge of the behaviour of charcoal.

The efficiency of the heating can be further improved by pre-heating. This requires arrangements such that already treated stones would give away heat to the incoming air, which in turn would heat previously unheated stones on exiting. Such arrangements have been known to man for many millennia in conjunction with burning of limestone [47].

Further considerations indicate that the space between the stones might have been sufficient for filling-in with the charcoal required for the fusion process.

\section{Discussion}

\subsection{Comparison of chemical composition}

A comparison between the vitrified waste forms discussed in Section 3 with the analogues discussed in Section 4 shows the following (see also Figure 1 and Section 5.1).

The natural glass obsidian has higher levels of silicon plus aluminium and lower levels of sodium plus potassium than any of the wastes. It is therefore much more durable than the different waste forms, and may show different corrosion and weathering behaviour, depending on the vitrified waste in question together with the particular environment.

The glasses in the archaeological artefacts have higher levels of sodium plus potassium as compared to the waste glasses and are known to corrode with different mechanisms at least compared to nuclear waste glasses [48-50]. 
The glasses in vitrified forts show large ranges of variation for the various elements that they contain [39-40], see also Figure 1. These ranges appear to cover those of the various waste forms reasonably well with the exception of nuclear glass which contains high levels of phosphorus. It should not be ruled out, however, that such anthropogenic glass might be found since the stone walls in the hillforts are known to sometimes contain considerable amounts of bone material (generated as a residue from the consumption of meat).

\subsection{Method used for vitrification}

The properties of a glass do not depend only on its chemical composition, but also on the manufacturing process [51]. The rate of cooling at different temperatures is particularly important. It is therefore warranted to analyse whether the ancient processes might be reproduced, and comparisons be made with modern waste glasses.

The quality of heat based analysis in Section 5.2 shows that it is unlikely that the vitrification in the hillforts was achieved by enemies just burning the reinforcing logs in the ramparts. Too little heat would have been supplied at the relevant high temperatures.

Instead, charcoal was probably used in combination with preheating. It is also possible that bellows were used. Another possibility is the addition of simple clay stoves at the inlets of air to the stone structures.

The feasibility of such arrangements can be tested relatively easily. The results of such tests would allow comparison to be made with modern waste vitrification processes, and conclusions to be drawn regarding the relevance of the analogues and the validity of the comparison of durability.

\section{Conclusions}

The main conclusion of the present work is that vitrified stone material in a large number of hillforts constitutes good analogues for vitrified waste. The compositions vary considerably from site to site and even within any particular site so that the range of parameters for the chemical composition covers those of the waste glasses for most major elements.

Natural glass as well as archaeological glass artefacts shows much narrower ranges that also deviate substantially from those of the glasses containing waste. No record has been found in the literature on the use of glass in vitrified forts as anthropogenic analogues for vitrified waste. The results in this paper indicate that such work may be highly warranted.

Quality of heat based analyses in this paper has resulted in conclusions on the types of methods that might have been used for the melting of the glass. No record has been found in the literature on anyone using this approach. As a consequence of the analysis, it appears plausible that the ancient methods used may be reasonably reproduced today, such that comparisons can be made between the genesis of the glass in the vitrified forts and the generation of glasses containing waste. This can, in turn, be expected to enable comparisons to 
be made with regard to durability, thus providing validation of the use of the analogue. Such tests are therefore also highly recommended.

\section{Further work}

The authors are in the process of submitting a more comprehensive account of this work to the International Journal of Sustainable Development and Planning.

\section{Acknowledgements}

This work was made possible through a grant from Ångpanneföreningens Forskningsstiftelse (Ångpanneföreningen's Foundation for Research and Development), and this support is hereby gratefully acknowledged.

\section{References}

[1] Sakai, S. and Hiraoka, M., Municipal solid waste incinerator residue recycling by thermal processes. Waste Management 20, pp. 249-258, 2000.

[2] Ecke H., Sakanakura H., Matsuto T., Tanaka N. and Lagerkvist A., Stateof-the-art treatment process for municipal solid waste incineration residues in Japan. Waste Management and Research, 18, pp. 41-51, 2000.

[3] Christensen, T. H., editor, Solid waste technology \& management. John Wiley and Sons, 2011.

[4] Ecke, H., Sakanakura, H., Matsuto, T., Tanaka, N. and Lagerkvist, A. Stateof-the-art treatment processes for municipal solid waste incineration residues in Japan. Waste Management \& Research, 18(1) pp. 41-51, 2000.

[5] Ecke, H., Sakanakura, H., Matsuto, T., Tanaka, N. and Lagerkvist, A. The effect of electric arc vitrification of bottom ash on the mobility and fate of metals. Environmental Science \& Technology, 35(7), pp 1531-6, 2001.

[6] Chandler, A. J., et al. (Editors), Municipal solid waste incineration residues. The International Ash Working Group. Studies in Environmental Science 67. Elsevier, 1997.

[7] Handbook. Vitrification technologies for treatment of hazardous and radioactive waste. U. S. Environmental Protection Agency, EPS/625/R92/002, May 1992.

[8] Campbell, B., Thompson, L. and Finucane, K., Geomelt vitrification: Status of recent developments and project results. ICEM'05: the 10th International Conference on Environmental Remediation and Radioactive Waste Management. September 4-8, Glasgow, Scotland.

[9] Luey, J., Roberts, J. S. and Timmerman, C. L., Implementation of in situ vitrification for contaminated soils. Presented at the American Institute of Chemical Engineers National Summer Meeting, August 15-18, 1993, Seattle Washington, USA.

[10] Thompson, L., Huddleston, G., Reichhart, D., Jones, J., Springer, M. and Campbell. B., Results from the non-traditional (sub-surface) in situ 
vitrification demonstration for mixed waste applications at the los Alamos National Laboratory. WM'01 Conference, February 25-March 1, 2001, Tucson, Arizona, USA.

[11] Ojovan, M. I. and Lee, W. E., An introduction to nuclear waste immobilisation. Elsevier Ltd., 2005.

[12] White, W. B., Theory of corrosion of glass and ceramics. In Clark, D. E. and Zoitos B. K., Corrosion of glass, ceramics and ceramic superconductors. Principles, testing, characterization and applications. Noyes Publications, 1992.

[13] Grambow, B., Geochemical approach to glass dissolution. In Clark, D. E. and Zoitos B. K., Corrosion of glass, ceramics and ceramic superconductors. Principles, testing, characterization and applications. Noyes Publications, 1992. ISBN 0-8155-1283-X.

[14] Plodinec, M.J., Wicks, G. G. and Bibler, N. E., An Assessment of Savannah River Borosilicate Glass in the Repository Environment. DP-1629, Savannah River Laboratory, Aiken, South Carolina, 1982.

[15] Ralston I., Celtic fortifications. Tempus Publishing Ltd., 2000.

[16] M'Hardy, A.B., On vitrified forts, with results of experiments as to the probable manner in which their vitrification may have been produced. Proc. Soc. Antiq. Scot. 40, pp. 136-150, 1906.

[17] Kresten, P., The Vitrified forts of Europe: saga, archaeology and geology. In: Pecchio, M. et al. (Eds.), Applied Mineralogy: Developments in Science and Technology, Sao Paolo, pp. 355-357, 2004.

[18] MacKie, E.W., The Vitrified Forts of Scotland. In: Harding, D.W. (Ed.), Hillforts, Later Prehistoric Earthworks in Britain and Ireland. Academic Press, London, pp. 205-235, 1976.

[19] Yang, Y., Xiao, Y., Voncken, J. H. L. and Wilson, N. Thermal treatment and vitrification of boiler ash from a municipal solid waste incinerator. Journal of Hazardous Materials, 154(1-3), pp 871-9, 2008.

[20] Lin, K. L., Huang, W. J., Chen, K. C., Chow, J. D. and Chen, H. J. Behaviour of heavy metals immobilized by co-melting treatment of sewage sludge ash and municipal solid waste incinerator fly ash. Waste Management \& Research, 27(7) pp 660-7, 2009.

[21] Romero, M., Hernández-Crespo, M. S. and Rincón, J. M. Leaching behaviour of a glassy slag and derived glass ceramics from arc plasma vitrification of hospital wastes. Advances in Applied Ceramics: Structural, Functional \& Bioceramics, 108(1) pp67-71, 2009.

[22] Sobiecka, E., Cedzynska, K. and Smolinska, B. Vitrification as an alternative method of medical waste stabilization. Fresenius Environmental Bulletin, 19(12A), pp3045-8, 2010.

[23] Saffarzadeh, A., Shimaoka, T., Motomura, Y. and Watanabe, K. Characterization study of heavy metal-bearing phases in MSW slag. Journal of Hazardous Materials, 164(2-3), pp 829-34, 2009.

[24] Zhao, P., Ni, G. H., Jiang, Y. M., Chen, L. W., Chen, M. Z. and Meng, Y. D. Destruction of inorganic municipal solid waste incinerator fly ash in a 
DC arc plasma furnace. Journal of Hazardous Materials, 181(1-3), pp 5805, 2010.

[25] Tu, X., Yu, L., Yan, J. H., Cen, K. F. and Cheron, B. G. Plasma Vitrification of Air Pollution Control Residues From Municipal SolidWaste Incineration. Ieee Transactions on Plasma Science, 38(12), pp 3319$25,2010$.

[26] Wang, Q., Yan, J. H., Chi, Y., Li, X. D. and Lu, S. Y. Application of thermal plasma to vitrify fly ash from municipal solid waste incinerators. Chemosphere, 78(5), pp 626-302010.

[27] Roether, J. A., Daniel, D. J., Amutha Rani, D., Deegan, D. E., Cheeseman, C. R. and Boccaccini, A. R. Properties of sintered glass-ceramics prepared from plasma vitrified air pollution control residues. Journal of Hazardous Materials, 173(1-3), pp 563-9, 2010.

[28] Wang, Q., Yan, J. H., Tu, X., Chi, Y., Li, X. D., Lu, S. Y. and Cen, K. F. Thermal treatment of municipal solid waste incinerator fly ash using DC double arc argon plasma. Fuel, 88(5), pp 955-8, 2009.

[29] Kuo, Y.-M., Tseng, H.-J., Chang, J.-E., Wang, J.-W., Wang, C.-T. and Chen, H.-T. An alternative approach for reusing slags from a plasma vitrification process. Journal of Hazardous Materials, 156(1-3), pp 442-7, 2008.

[30] Kuo, Y. M., Wang, C. T., Tsai, C. H. and Wang, L. C. Chemical and physical properties of plasma slags containing various amorphous volume fractions. Journal of Hazardous Materials, 162(1), pp 469-75, 2009.

[31] Gomez, E., Rani, D. A., Cheeseman, C. R., Deegan, D., Wise, M. and Boccaccini, A. R. Thermal plasma technology for the treatment of wastes, A critical review. Journal of Hazardous Materials, 161(2-3), pp 614-26, 2009.

[32] Yang, J. K., Xiao, B. and Boccaccini, A. R. Preparation of low melting temperature glass-ceramics from municipal waste incineration fly ash. Fuel, 88(7), pp 1275-80, 2009.

[33] Sakai, S.-i. and Hiraoka, M. Municipal solid waste incinerator residue recycling by thermal processes. Waste Management, 20(2-3), pp 249-58, 2000.

[34] Oresek, N., Berk, F., Samec, N. and Zupanic, F. Fly ash immobilization with vitrification. Materiali in Tehnologije, 44(6), pp 373-8, 2010.

[35] Lin, K. L. and Chang, C. T. Leaching characteristics of slag from the melting treatment of municipal solid waste incinerator ash. Journal of Hazardous Materials, 135(1-3), pp 296-302, 2006.

[36] Monteiro, R. C. C., Alendouro, S. J. G., Figueiredo, F. M. L., Ferro, M. C. and Fernandes, M. H. V. Development and properties of a glass made from MSWI bottom ash. Journal of Non-Crystalline Solids, 352(2), pp 130-5, 2006.

[37] Goffer, Z., Archaeological chemistry, 2nd edition. John Wiley and Sons, 2007.

[38] Le Bourhis, E., Glass. Mechanics and technology. Wiley-VCH Verlag $\mathrm{GmbH}$ and Co., 2008. 
[39] Kresten, P., and Ambrosiani, B., Swedish vitrified forts - a reconnaissance study. Fornvännen, 87, pp. 1-17, 1992.

[40] Friend, C. R. L., Dye, J., Fowler, and M. B. New field and geochemical evidence from vitrified forts in South Morar and Moidart, NW Scotland: further insight into melting and the process of vitrification. Journal of Archaeological Science, 34, pp. 1685-1701, 2007.

[41] Kresten, P., Goedicke, C., and Manzano, A., TL - dating of vitrified material. Geochimometria - Journal on Methods and Applications of Absolute Chronology, 22, pp. 9-14, 2003.

[42] Kresten, P., Kero, L., and Chryssler, J., Geology of the vitrified hill-fort Broborg in Uppland, Sweden. Geologiska Föreningen i Stockholm Förhandlingar, 115, pp. 13-24, 1993.

[43] Karlebo handbok. Maskinaktiebolaget Karlebo, Stockholm, 1936.

[44] Diaz-Martinez, E., Soares, A.M.M., Kresten, P., and Glazovskya, L., Evidence for wall vitrification at the Late Bronze Age settlement of Passo Alto (Vila Verde de Ficalho, Serpa, Portugal). Rev. Port. Arqueol. 8, pp. 151-161, 2005.

[45] Friend, C.R.L., Charnley, N.R., Clyne, H., and Dye, J., Experimentally produced glass compared with that occurring at The Torr, NW Scotland, UK: vitrification through biotite melting. Journal of Archaeological Science, 35, Issue 12, pp. 3130-3143, December, 2008.

[46] Youngblood, E., Fredriksson, B.J., Kraut, F., and Fredriksson, K., Celtic vitrified forts: implications of a chemical-petrological study of glasses and source rocks. J. Arch. Sci., 5, pp. 99-121, 1978.

[47] Oates, J. A. H., Lime and limestone. Wiley-VCH, 1998.

[48] Jercinovic, M. J. and Ewing, R. C., Corrosion of geological and archaeological glasses. In Clark, D. E. and Zoitos B. K., Corrosion of glass, ceramics and ceramic superconductors. Principles, testing, characterization and applications. Noyes Publications, 1992.

[49] McLoughlin, S. D., Hyatt, N. C., Hand, R. J. and Lee, W. E., Corrosion of archaeological model glasses after 32 years of burial at Ballidon. Mat. Res. Soc. Symp. Proc. 932, 2006.

[50] Jantzen, C. M., Thermodynamic approach to glass corrosion. In Clark, D. E. and Zoitos B. K., Corrosion of glass, ceramics and ceramic superconductors. Principles, testing, characterization and applications. Noyes Publications, 1992.

[51] Kuo, Y. M., Wang, J. W., Chao, H. R., Wang, C. T. and Chang-Chien, G. P. Effect of cooling rate and basicity during vitrification of fly ash Part 2. On the chemical stability and acid resistance of slags. Journal of Hazardous Materials, 152(2), pp 554-62, 2008. 